\title{
ANALISA KANDUNGAN POLIAROMATIK HIDROCARBON PADA GAS BUANG KENDARAAN BERMOTOR BERBAHAN BAKAR DIESEL, AIR LAUT DAN SEDIMEN YANG TERKONTAMINASI TUMPAHAN MINYAK
}

\author{
Lilik Zulaihah \\ Program Studi Teknik Industri, Fakultas Teknik \\ Universitas Pembangunan Nasional "Veteran" Jakarta \\ JI. RS Fatmawati Pondok Labu Jakarta Selatan 12450
}

\begin{abstract}
$P A H$ tend to bind with organic and inorganic material suspended so abundant in bottom sediments. PAHs enter the water through various sources are quickly absorbed by organic and inorganic particles. PAH accumulated by aquatic biota higher than womb environment. This study aims to determine the type and content of polyaromatic hydrocarbons both in the exhaust emissions of motor vehicles as well as diesel fuel in sea water and sediments contaminated by the oil spill. The results showed that Chrysene, benzo (b) Fluoranthene and Benzo (a) Pyrene is a sample that had higher levels of $P A H$ is quite high and is found in every sample well on exhaust emissions as well as in seawater and sediments, where all three types of $P A H$ that exceed the threshold determined doubled. While the content of PAHs found in terminal loading and unloading of ships Benzo (b) fluoren namely 92.842 ppm and below Benzo (a) pyren 62.054 ppm and 10.939 Chrysene pp.
\end{abstract}

\section{PENDAHULUAN}

Pembangunan di sektor industri transportasi selain menghasilkan produk atau manfaat utama, juga menghasilkan produk yang tidak diinginkan yaitu berupa limbah baik padat, cair maupun gas yang mengakibatkan terjadinya polusi yang dapat membahayakan kehidupan manusia dan mahluk hidup yang lain. Limbah gas umumnya dihasilkan dari proses pembakaran bahan bakar fosil baik yang dilakukan pada furnace industri, rumah tangga maupun yang berasal dari mesin kendaraan bermotor dan lain nya. Kontribusi pencemar udara terbesar adalah dari sektor transportasi $55,4 \%$ dan industri $36,5 \%$ dan $8,1 \&$ berasal dari yang lainnya. Dengan meningkatnya jumlah kendaraan bermotor dan sering terjadinya kemacetan, khususnya di DKI jakarta tanpa disadari telah meningkat pemakaian bahan bakar yang diiringi dengan meningkatnya emisi gas buang, yang berdampak meningkatnya konsentrasi bahan pencemar di udara.

Dalam kegiatan reparasi kapal terutama saat pekerjaan tank cleaning bahan bakar pada graving dock PT. Dok dan Perkapalan Koja Bahari (persero) di Tanjung Priok Jakarta Utara terjadi tumpahan minyak di lantai graving dock yang kemudian akan bercampur dengan air laut. Selama ini untuk menetralisir limbah yang terbentuk di sekitar lantai graving dock, telah dilakukan dengan memberikan senyawa kimia, dengan harapan senyawa tersebut dapat bereaksi dengan logam berat dan limbah beracun lainnya, sehingga kualitas air laut di sekitar galangan kapal memenuhi standar kulitas air yang ditetapkan Kementerian Perhubungan, Departemen Perhubungan Laut.

Dengan dimasukkannya PAH sebagai salah satu parameter penentu kualitas air laut dan udara, maka perlu dilakukan penelitian untuk memperoleh gambaran seberapa banyak jenis dan konsentrasi kandungan PAH yang terdapat pada air dan konsentrasi partikulat yang ada di udara.

Pengukuran kandungan poliaromatik hidrokarbon pada air laut dan sedimen dilakukan dengan cara pengambilan sampel yang diduga sebagai pusat terjadinyan tumpahan minyak, sedangkan untuk pengukuran $\mathrm{PAH}$ secara 
kuantitatif pada emisi gas buang kendaraan bermotor, dilakukan dengan cara pengambilan sampel melalui penyerapan oleh adsorben yang dipasang pada knalpot kendaraan bermotor, yang merupakan pusat terbentuknya emisi PAH berupa partikulat.

Untuk mengetahui kandungan emisi poliaromatik hidrokarbon (PAH) baik pada air laut maupun pada emisi gas buang kendaraan bermotor, perlu dilakukan penelitian analisis kandungan $\mathrm{PAH}$ pada gas buang kendaraan bermotor maupun pada air laut yang terkontaminasi oleh tumpahan minyak.

\section{TINJAUAN PUSTAKA}

Salah satu kontaminan lingkungan penting dan termasuk bahan kimia beracun adalah kandungan Poly Aromatic Hydrocarbon (PAH), yang merupakan senyawa organic yang mempunyai cincin aromatic lebih dari satu dalam satu molekul hydro carbon. Senyawa ini dapat ditemui di semua lingkungan, baik daratan, lautan maupun udara. PAH masuk ke lingkungan khususnya di perairan laut melalui hujan, buangan industri, tumpahan minyak transportasi dan buangan dari daratan melalui muara sungai. Penelitian tentang PAH di ligkungan galangan kapal, merupakan proses yang penting, untuk menentukan kualitas lingkungan melalui penentuan kemungkinan pengaruhnya terhadap suatu ekosistem.

Dikarenakan sifatnya yang beracun, tahan lama dan karsinogenik, maka sumber dan distribusi PAH dalam suatu wilayah telah menjadi perhatian dan kajian utama dalam penelitian ini. Sifat PAH bervariasi baik yang mudah menguap maupun yang tidak mudah menguap. Senyawa ini pada perairan laut ditemukan dalam bentuk minyak mengapung, emulsi dan fraksi terendap di dasar perairan serta dapat berinteraksi dengan partikel lain, sehingga bersifat persiten terhadap lingkungan. Salah satu yang akhir-akhir ini menjadi perhatian adalah pencemar PAH. Komponen minyak sebagai sumber pencemar antara lain berasal dari buangan air balast, ceceran bahan bakar mesin-mesin kapal dan buangan oli bekas di daratan.

PAH terdiri dari 2 atau lebih rantai karbon siklik yang memiliki stabilitas yang tinggi di lingkungan, mempunyai sifat hidrophobik yang tinggi dan struktur kimia yang stabil, sifatnya tidak mudah larut dan dapat dengan cepat terserap melalui partikel tanah, terutama pada bahan bahan organik. Distribusi dan fase PAH sebagai kontaminan organik di sedimen pada ekosistem perairan sangat perlu diperhatikan karena mempunyai efek mutagenik dan karsinogenik. "Konsentrasi PAH dalam tingkat tertentu di air laut dan sedimen dapat bersifat toksin terhadap organisme laut bentik dan pelagic".

Di udara molekul-molekul PAHs akan bergabung dengan partikel debu dan masuk ke dalam air, tanah maupun tanaman untuk kemudian berinteraksi dengan manusia ATSDR (Agency for Toxic Subtances and Disease Registry) mendeteksi adanya benzo(a)pyrene pada buah-buahan, sayuran, daging, minuman dan tembakau yangberedar di pasaran. Namun yang pasti, pembentukan benzo(a)pyrene pada makanan sangat tergantung dari metode pemasakan yang digunakan.Telah terbukti bahwa kandungan senyawa PAHs karsinogenik pada makanan yangdipanggang cukup tinggi, terutama pada produk hasil pemanggangan dengan kayu atauarang. Pada daging panggang (babi dan sapi) terkandung benzo(a)pyrene sebesar 1,4-4,5 ppb, sate kambing23 ppb, ikan asap Jepang 37 ppm, dan pada minyak goreng bekas 1,4-4,5 ppb. Proses pemanggangan dengan oven menghasilkan produk olahan dengan kandungan senyawa PAH yang terendah, sedangkan pemasakan dengan microwave tidak menghasilkan senyawa PAH yang karsinogenik.

Benzo[a]piren adalah salah satu senyawa yang menginduksi enzim sitokrom P450 dan mempercepat metabolisme dari beberapa obat, misal teofilin, Benzo[a]piren, C20H12 adalah lima cincin polisiklik aromatik hidrokarbon yang bersifat mutagenik dan sangat karsinogenik. Benzo[a]piren berbentuk kristal kuning yang padat. Benzo[a]piren adalah produk yang tidak sempurna dari pembakaran pada temperatur antara $300^{\circ} \mathrm{C}$ dan $600^{\circ} \mathrm{C}$. Benzo[a]piren dapat ditemukan pada permukaan batubara, gas buangan terutama dari mesin diesel, dan asap rokok. Penelitian baru-baru ini diketahui bahwa tingkat benzo[a]piren pada makanan yang dipanggang atau dibakar secara signifikan lebih tinggi daripada yang tidak dipanggang, meskipun tidak menutup kemungkinan bahwa makanan yang tidak dipanggang tidak bersifat karsinogenik. Senyawa kimia yang ditemukan dalam perokok tembakau yaitu benzo[a]piren dapat menyebabkan kerusakan genetik pada sel paru yang identik dengan kerusakan pada 


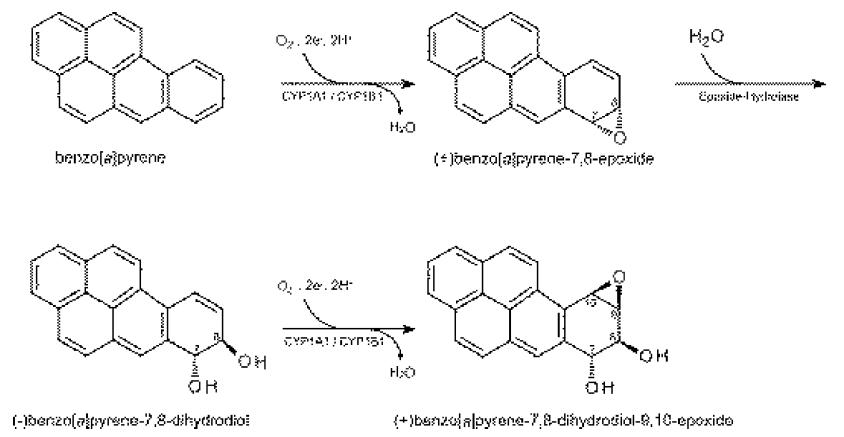

Anjuran batas kandungan PAHs oleh The Occupational Safety and HealthAdministration (OSHA) membatasi 0,2 milligrams PAHs per kubik meter udara $(0,2 \mathrm{mg} / \mathrm{m} 3)$. OSHA permissible Exposure Limit (PEL) $5 \mathrm{mg} / \mathrm{m} 3$ PAHs untuk mineral oil. Sedangkan National Institute for Occupational Safety and Health (NIOSH) menganjurkan jumlah PAH maksimal 0,1 mg/m3 udara untuk daerah tempat kerja dengan waktu kerja $10 \mathrm{jam} / \mathrm{hari}$ dan $40 \mathrm{jam} / \mathrm{minggu}$. Agency for Toxic Subtancesand Disease Registry (ATSDR) merekomendasikan nilai MRL (Minimal Risk Level)benzo(a)pyrene pada manusia sebesar 0,01 $\mathrm{ppm} / \mathrm{kg} \mathrm{BB} /$ hari. Sedangkan beberapa Negara telah membatasi jumlah benzo(a) pyrene minimal sebasar 1 ppb untuk bahan pangan yang dipanggang dan diasap.

Mekanisme pembentukan molekul PAH terjadi melalui reaksi pemecahan bahan organik menjadi fragmen yang sederhana (pirolisis) dan pembentukan senyawa aromatik dari fragmen tersebut (pirosintetik) (Morret et al. 1999; CanoLerida et al. 2008). Selain melalui mekanisme suhu tinggi $\left(200-800^{\circ} \mathrm{C}\right)$, molekul PAH diketahui dapat terbentuk pada suhu yang relatif rendah, sekitar $100-150^{\circ} \mathrm{C}$, namun dengan waktu yang lebih panjang dibandingkan pirolisis dan pirosintesis (Morret et al. 1999). PAH umumnya bersifat sangat hidrofobik dikarenakan strukturnya yang memiliki banyak cincin aromatik yang bersifat nonpolar.

Logam berat di perairan, berbahaya baik secara langsung terhadap kehidupan organisme, maupun efeknya secara tidak langsung terhadap kesehatan manusia. Hal ini berkaitan dengan sifatsifat logam berat yaitu:

a. Sulit didegradasi, sehingga mudah terakumulasi dalam lingkungan perairan dan keberadaannya secara alami sulit terurai (dihilangkan)

b. Dapat terakumulasi dalam organisme termasuk kerang dan ikan, dan akan membahayakan kesehatan manusia yang mengkomsumsi organisme tersebut c. Mudah terakumulasi di sedimen, sehingga konsentrasinya selalu lebih tinggi dari konsentrasi logam dalam air. Disamping itu sedimen mudah tersuspensi karena pergerakan masa air yang akan melarutkan kembali logam yang dikandungnya ke dalam air, sehingga sedimen menjadi sumber pencemar potensial dalam skala waktu tertentu.

Menurut NEFF proses pembakaran sangat mempengaruhi jenis dan jumlah $\mathrm{PAH}$ yang dihasilkan. Sumber PAH di alam adalah pembakaran fosil fuel.kepekatan tertinggi PAH diperoleh dalam sedimen laut yang dekat dengan daerah perkotaan. Ini mungkin merupakan pola umum karena PAH cenderung berkumpul dalam sedimen perairan yang dekat dengan daerah perkotaan. Senyawa PAH mudah mengendap ke dasar perairan, dan sangat beracun bagi organisme perairan. PAH yang terlarut dalam air, pada kadar antara 0,1 hingga $0,5 \mathrm{ppm}$ sudah dapat menyebabkan keracunan terhadap semua larva biota perairan, senyawa PAH akan terakumulasi menjadi kadar yang tinggi dalam tubuh hewan tingkat rendah, karena senyawa ini sukar dicerna dalam tubuhnya

PAH dalam air dan sedimen di perairan Teluk Klabat telah dilakukan pada bulan Maret dan Juli 2006. Kadar PAH diukur dengan Gas Cromatografi-Flame Ionisasi Detector (GC-FID) yang dilengkapi dengan kolom kapiler HP1. Hasil yang diperoleh menunjukkan bahwa kadar PAH total dalam air laut pada bulan Maret berkisar antara 0,375 - 44,486 ppb,dengan rata-rata 7,468 ppb, sedangkan pada bulan Juli antara 1,329 - 27,826 ppb, dengan rata-rata15,200 ppb. Kadar PAH total dalam sedimen pada bulan Maret berkisar antara 0,029-0,209 ppm, dengan rata-rata sebesar 0,106 ppm sedang bulan Juli berkisar antara 1,002 4,792 ppm, dengan rata-rata sebesar 1,928 ppm (part per million). Konsentrasi PAH dalam perairan Teluk Klabat sudah melebihi Baku Mutu Kualitas Perairan yang dikeluarkan oleh Kantor Menteri Negara Lingkungan Hidup 2004.

\section{BAHAN DAN METODOLOGI PENELITIAN}

Gas buang yang digunakan dalam penelitian ini diambil langsung dari knalpot kendaraan motor 
diesel jenis Taft GT, dengan menggunakan adsorben jenis Amberlite XAD-7. Adsorben sebanyak 15 gram dilakukan pencucian dengan menggunakan aquades dan ethanol masing-masing sebanyak 5kali, kemudian dipanas pada suhu $200^{\circ} \mathrm{C}$ selama $1 \mathrm{jam}$, kemudian disimpan pada suhu $-10^{\circ} \mathrm{C}$. Dalam pengambilan sampel mesin kendaraan dinyalakan sampai suhu konstan, alat filtrasi aerosol yang sudah berisi adsorben dipasang pada knalpot, laju alir gas diatur pada kecepatan yang di variasi yaitu pada 30 liter per menit, 45 liter per menit dan 60 liter per menit. Sampel disimpan pada suhu $-10^{\circ} \mathrm{C}$.

Air laut diambil dengan menggunakan water sampler sebanyak 2,5 liter, dimasukkan ke dalam botol berwarna, kemudian disimpan dalam Ice box. Setelah sampai di laboratorium setempat contoh air laut dilakukan preparasi contoh. Air laut disaring dengan kertas saring GFC (Glass Fiber type $C$ ) dan diekstrak dalam corong pisah dengan n.Heksan p.a sebanyak 120 mL. Proses selanjutnya dengan proses clean up menggunakan kolom khromatografi alumina WB5 basic SIGMA sebanyak 4 gram dan dialirkan. Heksan sesuai set pointnya. Sampel Clean Up diuapkan sampai 1 $\mathrm{mL}$ dan difraksinasi dengan kolom kromatografi silika merek 7754 sebanyak 4 gram menjadi fraksi polar (F2) untuk analisa PAH. Kadar PAH dengan detector FID Gas Chromatografi 5890 series 11. Hasil pengukuran dinyatakan dalam PCB dan $\mu \mathrm{g} / \mathrm{L}$ (ppb) untuk PAH.

Sedimen permukaan diambil dengan menggunakan grap dan langsung disimpan dalam bool sampel. Sampel sedimen ditimbang sekitar 40gram untuk analisa senyawa organik dan dioven sehari dalam suhu $60^{\circ} \mathrm{C}$ dan 10 gram untuk penentuan kadar airnya yang dioven dalam suhu $105^{\circ} \mathrm{C}$. Sampel sedimen yang sudah ditimbang dihaluskan dengan menambahkan Na2SO4 sampai halus dan diekstraksi dengan dikhlorometan (DCM) dalam Soxhlet selama 8 jam. Setelah itu dipekatkan menggunakan alat Kuderma Danish evaporator sampai $1 \mathrm{ml}$. Langkah selanjutnya yaitu proses clean updan fraksinasi. Hasil pengukuran PCB dalam sampel sedimen dinyatakan dalam $\mathrm{mg} / \mathrm{kg}$ (ppm).

\section{HASIL DAN PEMBAHASAN}

Parameter pencemar udara ambien menurut Peraturan Pemerintah Nomor 41 tahun 1999, meliputi : Sulfur dioksida (SO2), Karbon monoksida (CO), Nitrogen dioksida (NO2), Oksidan (O3), Hidro karbon (HC), PM 10 , PM 2,5, TSP (debu), Pb (Timah Hitam), Dustfall (debu jatuh). Sedangkan parameter udara indoor mengacu pada Permenkes No 1077 tahun 2011 tentang Pedoman Penyehatan Udara dalam Ruang Rumah, yaitu Suhu, Pencahayaan, Kelembaban, Laju ventilasi, PM2,5, PM10, SO2, NO2, Ozon, CO2, $\mathrm{CO}$, Timbal $(\mathrm{Pb})$, Asbes, Formaldehid (HCHO), Volatile Organic compound (VOC), Environmental Tobaco Smoke (ETS), bakteri pathogen dan jamur.

PAH dikelompokkan menjadi dua, yaitu PAH dengan bobot molekul rendah yang berupa senyawa dengan cincin aromatik 3 dan $\mathrm{PAH}$ dengan bobot molekul tinggi yang berupa senyawa dengan cincin aromatik $>3$. PAH masuk kedalam air melalui berbagai sumber yang dengan cepat diabsorpsi oleh partikel organic dan anorganik. PAH yang masuk ke lingkungan perairan dapat dibedakan menjadi pirogenik dan petrogenik.Pergerakan PAH di lingkungan tergantung pada propertinya seperti mudahnya PAH larut di air dan mudahnya PAH menguap ke atmosfir.

1. Kandungan PAH pada gas buang kendaraan bermotor berbahan bakar solar dengan menggunakan adsorben XAD-7

Untuk mendapatkan kondisi yang baik, pada pengambilan contoh dilakukan variasi laju pembakaran bahan bakar/laju alir gas buang pada 30, 45 dan 60 liter per menit serta waktu pengambilan contoh selama 50 menit. Suhu adsorben tidak divariasi, akan tetapi diamati, yaitu pada laju pembakaran/laju alir gas buang pada 30 dan 45 liter permenit suhu adsorben menunjukkan antara 20 sampai $40^{\circ} \mathrm{C}$, sedangkan pada laju pembakaran/laju alir gas buang pada 60 liter per menit antara 20 sampai $53^{\circ} \mathrm{C}$. Setelah di adsorpsi kadar PAH dari emisi gas buang diukur dengan menggunakan alat kromnatografi gas.

Penelitian yang sudah dilakukan dengan melakukan pengambilan sampel pada knalpot kendaraan bermotor berbahan bakar diesel, dengan variabel waktu dan kevepatan laju alirg gas, kemudian dilakukan pemeriksaan pada lebaga Oceangrafi untuk mengetahui jumlah jenis dan konsentrasi PAH. Kadar PAH yang diperoleh dengan menggunakan adsorben amberlite XAD7 dengan variabel waktu 50 menit telah menunjukkan kenaikan yang signifikan, yaitu 
dengan dinaikkannya laju alir gas buang kendaraan bermotor. Pada laju alir 30 liter permenit kadar PAH sebanyak 48,0 ppm, pada 45 liter per menit 76,0 ppm dan pada 60 liter permenit sebesar 126,0 ppm.

Tabel 1.1 Kandungan PAH pada emisi gas buang kendaraan bermotorpada laju alir gas 30,45 dan 60 liter per menit selama 50 menit

\begin{tabular}{|l|r|r|r|}
\hline JENIS PAH & $\begin{array}{r}\text { Laju alir } \\
\text { 30lt/ } \\
\text { menit }\end{array}$ & $\begin{array}{r}\text { Laju alir } \\
30 l t / \\
\text { menit }\end{array}$ & $\begin{array}{r}\text { Laju alir } \\
601 \mathrm{t} / \\
\text { menit }\end{array}$ \\
\hline Naphthalene & - & 1,0 & 27,0 \\
Acenaphthylene & 4,0 & 1,0 & 8,0 \\
Acenaphthalene & 3,0 & 1,0 & 12,0 \\
Fluorene & 9,0 & 39,0 & 35,0 \\
Anthracene & 15,0 & 15,0 & 33,0 \\
Phenanthrene & 4,0 & 8,0 & 11,0 \\
Fluorantene & 4,0 & 3,0 & 5,0 \\
Pyrene & 5,0 & 2,0 & 8,0 \\
Chrysene & - & 2,0 & 5,0 \\
Benzo(b)Fluorene & - & 1,0 & 2,0 \\
Benzo(A)Pyrene & 4,0 & 4,0 & 7,0 \\
Total PAH & 48,0 & 76,0 & 126,0 \\
\hline
\end{tabular}

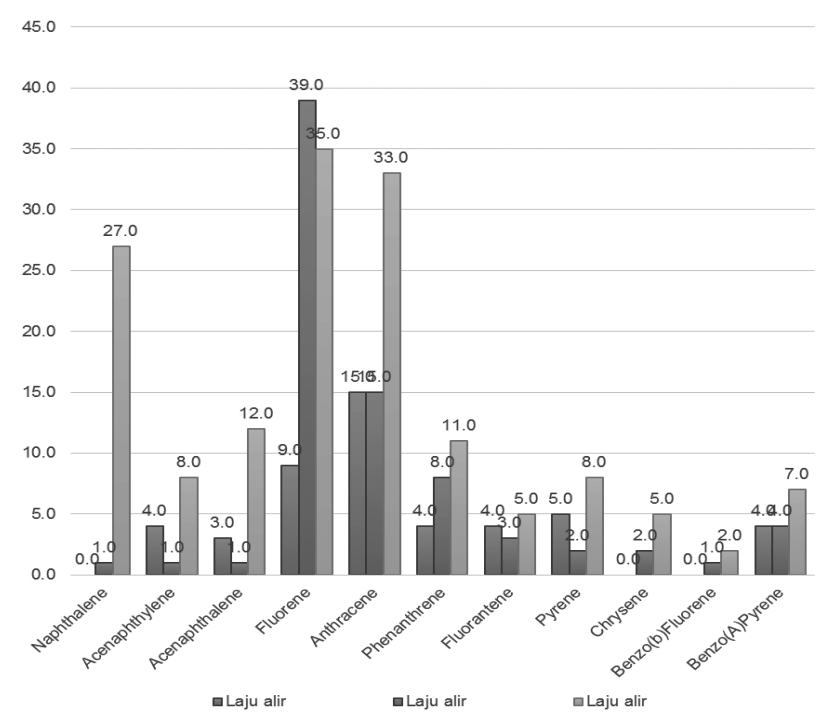

Grafik 1. 1 Kandungan PAH pada emisi gas buang kendaraan bermotor pada laju alir gas 30, 45 dan 60 liter per menit selama 50 menit

Hasil penelitian menunjukkan total $\mathrm{PAH}$ yang dapat terserap oleh adsorben amberlite XAD7 cukup tinggi, khususnya untuk jenis Benzo(a) pyrene masing-masing menunjukkan 4,0 ppm untuk laju alir 30 dan 45 liter per menit, sedangkan laju alir 60 liter per menit sebesat 7,0 ppm. Ini menunjukkan bahwa kadar PAH yang dikeluarkan oleh emisi gas buang sudah membahayakan manusia mengingat ambang batas yang diijinkan sesuai PP No 41 tahun 1999 menyebutkan ambang batas PAH(dalam debu) yang diizinkan dalam lingkungan adalah setara dengan $0,23 \mathrm{mg} / \mathrm{m} 3$.

Poliaromatik hidrokarbon (PAH) yang dikeluarkan oleh gas buang kendaraan bermotor ada dua fasa, yaitu fasa partikulat dan gas. PAH tersebut berasal dari bahan bakar dan dari hasil pembakaran yang tidak sempurna. Teknik pengambilan contoh yang digunakan adalah teknik filtrasi aerosol dengan menggunakan amberlite XAD-7 sebagai adsorben, dengan tujuan dapat menyerap PAH dari emisi gas buang kendaraan diesel.

Hidro karbon (HC) diudara akan bereaksi dengan bahan-bahan lain dan akan membentuk ikatan baru yang disebut plycyclic aromatic hidrocarbon $(\mathrm{PAH})$ yang banyak dijumpai di daerah industri dan padat lalu lintas. Bila PAH ini masuk dalam paru-paru akan menimbulkan luka dan merangsang terbentuknya sel-sel kanker. Kanker akibat pencemaran udara erat kaitannya dengan radikal bebas yang pada umumnya mengakibatkan ketidaknormalan dalam metabolisme tubuh.

2. Kandungan PAH pada air laut dan sedimen yang terkontaminasi tumpahan minyak di sekitar doct kapal dan terminal bongkar muat kapal

Kontaminasi PAH dalam suatu perairan dapat bersumber dari berbagai aktivitas baik aktivitas alami (perembesan minyak, asap kebakaran hutan, letusan gunung berapi) ataupun sumber antropogenik (kegiatan industri, transportasi dan aktivitas rumah tangga). Molekul PAH dengan bobot molekul besar (PAH > 3 cincin benzene) biasanya berasal dari pembakaran tidak sempurna (pirogenik) sedangkan PAH dengan bobot molekul kecil (PAH dengan 2-3 cincin benzene) sangat dominan dalam produk petroleum (petrogenik). Penelusuran sumber asal senyawa PAH dalam sedimen dapat dilakukan dengan metode diagnosa rasio. Metode diagnosa rasio dilakukan karena adanya perbedaan stabilitas termodinamika setiap senyawa PAH.

Untuk mengetahui sumber asal individu PAH digunakan metode diagnose rasio (Yunker el al, 2002). Ada beberapa rasio senyawa PAH yang digunakan yaitu rasio Phenanthrene/ anthracene (phe/anth) $>10$, menunjukkan bahwa $\mathrm{PAH}$ berasal dari minyak bumi, sedangkan $\mathrm{PAH}<$ 
10 menunjukkan bahwa PAH berasal dari pembakaran bahan organik dan sumber-sumber yang menghasilkan biomassa. Dari hasil penelitian menunjukkan bahwa rasio (phe/anth) rata2 (0,584/ $2,515=0,2322)<10$ menunjukkan bahwa PAH tersebut berasal dari sumber antropogenik (kegiatan industri, transportasi dan aktivitas rumah tangga). Pada kadar 10 ppm kandungan senyawa poliaromatik hidrokarbon dapat menyebabkan perubahan pola perilaku pada biota laut dan PAH pada kadar $>1000$ ppm dapat menyebabkan kematian. Keadaan ini berbahaya bagi organisme perairan yang hidup dan mencari makan di dalam sedimen perairan.

Tabel. 1.2 Kandungan PAH pada air laut di luar graving doct dan diterminal bongkar muat kapal serta pada sedimen pada lantai graving doct

\begin{tabular}{|l|c|c|c|}
\hline JENIS PAH & $\begin{array}{c}\text { Air laut } \\
\text { diluar graving } \\
\text { doct }\end{array}$ & $\begin{array}{c}\text { Air laut } \\
\text { diterminal } \\
\text { bongkar } \\
\text { muat }\end{array}$ & $\begin{array}{c}\text { Sedimen } \\
\text { di lantai } \\
\text { graving } \\
\text { doct }\end{array}$ \\
\hline Naphthalene & 0,368 & 0,269 & 0,279 \\
Acenaphthylene & 4,670 & 0,099 & 0,864 \\
Acenaphthalene & 0,030 & 0,183 & 1,195 \\
Fluorene & 11,000 & 0,104 & 2,080 \\
Anthracene & 8,770 & 0,821 & 2,785 \\
Phenanthrene & 0,277 & 0,479 & 0,000 \\
Fluorantene & 0,303 & 0,143 & 2,894 \\
Pyrene & 5,455 & 8,066 & 1,586 \\
Chrysene & 0,717 & 10,939 & 4,399 \\
Benzo(b)Fluorene & 4,059 & 92,842 & 2,525 \\
Benzo(A)Pyrene & 3,598 & 62,054 & 6,197 \\
Total PAH & 69,709 & 220,332 & 61,555 \\
\hline
\end{tabular}

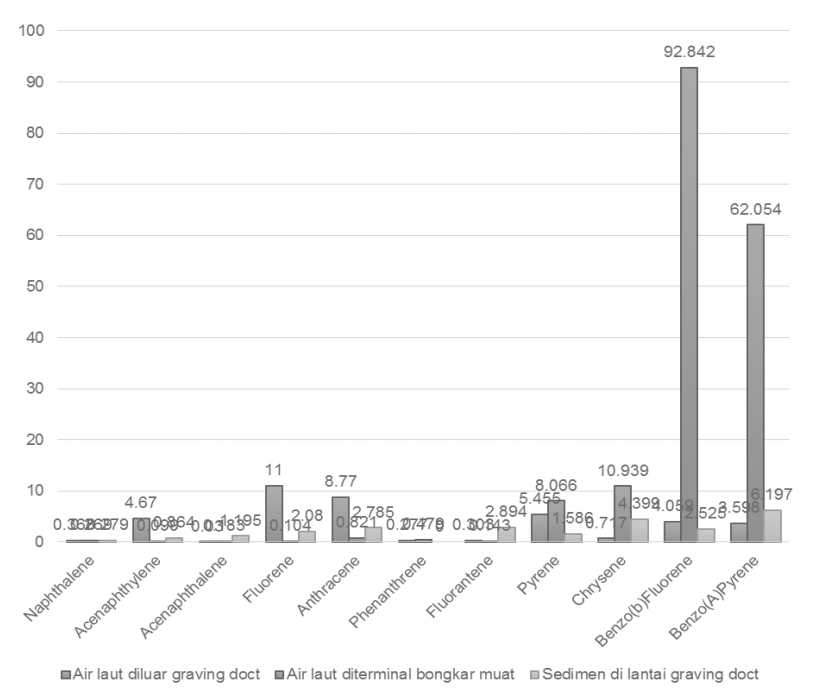

Grafik 1.2 Kandungan PAH pada air laut dan sedimen yang terkontaminasi tumpahan minyak di sekitar graving doct, terminal bongkar muat dan sedimen dengan

Dari hasil penelitian menunjukkan bahwa kadar fluorene 11,00 ppm merupakan kadar PAH paling tinggi yang terdapat pada air laut diluar graving doct. Sedangkan kadar PAH yang tedapat pada terminal bongkar muat yang tertinggi untuk jenis Benzo(b)fluoren yaitu 92,842 ppm dan yang dibawahnya Benzo(a)pyren 62,054 ppm dan Chrysene 10,939. Produk oksidasi metabolik menjadi penyebab dari kanker. Oksidasi enzimatik mengkonversi senyawa benzo(a)pirena menjadi diol-epoksida. Diol-epoksida ini kemudian bereaksi dengan DNA sel, menyebabkan mutasi dan mencegah sel bereproduksi secara normal. Ini menunjukkan bahwa air laut yang disekitar terminal bongkar muat sudah membahayakan bagi makluk hidup biota laut, mengingat tingginya kadar benzo(b)fluoren dan Benzo(a)pyren yang apabila terjadi reaksi oksidasi enzimatik akan menghasilkan Diol-epoksida kemudian bereaksi dengan DNA sel menyebabkan terjadinya mutasi dan mencegah sel bereproduksi secara normal.

Hidrokarbon aromatik polisiklik merupakan senyawa organik yang memiliki lebih dari empat cincin benzena terpadu atau lebih, bersifat karsinogenik. Benzena sendiri bersifat toksik dan agak karsinogenik. Dari beberapa hidrokarbon aromatik polisiklik ini yang paling bersifat karsinogen adalah benzo (a) pirena dan benzo antrasena.<smiles>c1ccc2c(c1)cc1ccc3cccc4ccc2c1c34</smiles>

Struktur kimia benzo[a]piren

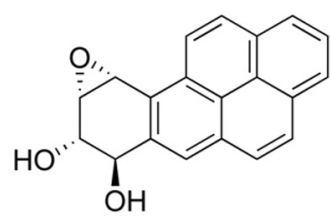

Struktur kimia dari benzo[a]piren yang karsinogenik

3. Kandungan PAH pada Gas buang kendaraan bermotor dengan air laut dan sedimen terkontaminasi tumpahan minyak.

Jenis PAH yang biasa terdapat di perairan adalah PAH naphthalene, anthracene, benzoanthracene dan benzopyrene. PAH cenderung berasosiasi (berikatan) dengan bahan organik dan anorganik tersuspensi sehingga banyak terdapat pada sedimen dasar. (Effendi, 2003). PAH masuk kedalam air 
melalui berbagai sumber yang dengan cepat diabsorpsi oleh partikel organic dan anorganik. Level PAH yang terakumulasi oleh biota perairan lebih tinggi dari kandungan lingkungan. PAH dapat berpindah melalui beberapa kegiatan seperti seperti fotoosidasi , oksidasi kimia, metabolism mikroba dan metabolisme oleh metazoan yang lebih tinggi. konsentrasi relative dari PAH pada ekosistem perairan secara umum adalah lebih tinggi pada sedimen, intermediate di biota akuatik, dan rendah di kolom perairan (Neff 1979).

Tabel 1.3 Kandungan PAH pada emisi gas buang kendaraan bermotor dan air laut seta sedimen terkontaminasi

\begin{tabular}{|l|r|l|l|r|r|r|}
\hline JENIS PAH & $\begin{array}{l}\text { D-Air } \\
\text { laut } \\
\text { diluar } \\
\text { graving } \\
\text { doct }\end{array}$ & $\begin{array}{l}\text { E-Air laut } \\
\text { diterminal } \\
\text { bongkar } \\
\text { muat }\end{array}$ & $\begin{array}{l}\text { C-Sedi } \\
\text { Men di } \\
\text { lantai } \\
\text { graving } \\
\text { doct }\end{array}$ & $\begin{array}{l}\text { Laju } \\
\text { alir 30 } \\
\text { lt/menit }\end{array}$ & $\begin{array}{l}\text { Laju } \\
\text { alir 45 } \\
\text { lt/menit }\end{array}$ & $\begin{array}{l}\text { Laju } \\
\text { alir 60 } \\
\text { lt/menit }\end{array}$ \\
\hline PAH & & & & & & \\
\hline Naphthalene & 0,368 & 0,269 & 0,279 & - & 1,0 & 27,0 \\
\hline Acenaphthylene & 4,670 & 0,099 & 0,864 & 4,0 & 1,0 & 8,0 \\
\hline Acenaphthalene & 0,030 & 0,183 & 1,195 & 3,0 & 1,0 & 12,0 \\
\hline Fluorene & 11,000 & 0,104 & 2,080 & 9,0 & 39,0 & 35,0 \\
\hline Anthracene & 8,770 & 0,821 & 2,785 & 15,0 & 15,0 & 33,0 \\
\hline Phenanthrene & 0,277 & 0,479 & 0,000 & 4,0 & 8,0 & 11,0 \\
\hline Fluorantene & 0,303 & 0,143 & 2,894 & 4,0 & 3,0 & 5,0 \\
\hline Pyrene & 5,455 & 8,066 & 1,586 & 5,0 & 2,0 & 8,0 \\
\hline Chrysene & 0,717 & 10,939 & 4,399 & - & 2,0 & 5,0 \\
\hline Benzo(b)Fluorene & 4,059 & 92,842 & 2,525 & - & 1,0 & 2,0 \\
\hline Benzo(A)Pyrene & 3,598 & 62,054 & 6,197 & 4,0 & 4,0 & 7,0 \\
\hline Total PAH & 69,709 & 220,332 & 61,555 & 48,0 & 76,0 & 126,0 \\
\hline
\end{tabular}

PAH jenis crysene juga ditemukan melebihi baku hampir di seluruh titik sampel di air laut maupun lumpur dan kawasan sekitarnya, sedangkan Benzoanthracene. PAH merupakan senyawa organik yang berbahaya dan bersifat karsinogenik. Tidak menyebabkan terbentuknya tumor ataupun kanker secara langsung, tetapi dalam sistem metabolisme tubuh akan diubah menjadi senyawa alkylating dihydrodiol epoxides yang sangat reaktif dan sangat berpotensi menyebabkan timbulnya tumor dan risiko kanker (UNEP, 2001). Dampaknya juga tidak bisa dilihat seketika. Butuh waktu 5 hingga 10 tahun untuk menemukan potensi kanker paru-paru; kanker kulit; dan kanker kandung kemih bagi manusia yang pernah terpapar dalam waktu lebih dari delapan jam.

\section{SIMPULAN}

Hasil penelitian menunjukkan bahwa kandungan total PAH yang terdapat pada emisi gas buang kendaraan bermotor berbahan bakar diesel adalah 46 ppm, 76 pp, dan 126 ppm, sedangkan yang tertinggi adalah Antrasen 15 ppm pada laju alir gas 30 liter per menit, Fluoren 39 ppm pada laju alir gas 45 liter per menit, Antrasene 33 ppm pada laju alir gas 60 liter per menit

Total Kandungan PAH pada air laut terkontaminasi yaitu diluar graving doct 69,709 ppm, terminal bongkar muat kapal 220,332 ppm dan pada sedimen $61,555 \mathrm{ppb}$, sedangkan kandungan PAH tertnggi terdapat pada terminal bongkar muat Chrysene 10,939, Benzo(b)Fluorene 92,842 ppm dan Benzo(a)pyrene 62,054 ppm.

Hasil penelitian menunjukkan bahwa Jenis PAH yang mempunyai kadar cukup tinggi dan ditemukan pada setiap sampel baik pada emisi gas buang maupun pada air laut dan sedimen adalah Chrysene, Benzo(B) Fluoranthene dan Benzo(a) Pyrene, dimana ketiga jenis PAH tersebut melebihi ambang batas yang ditentukan berlipat ganda.

\section{DAFTAR PUSTAKA}

Dina Augustine, 2008, Akumulasi Hidrokarbon Aromatik Polisiklik (PAH) Dalam Kearang 
Hijau (Pernaviridis) DiPerairan Kamal Muara, Teluk Jakarta, Tahun

Fasmi Ahmad, 2012, Kandungan Senyawa Polisiklik Aromatik Hidrokarbon (PAH) di Teluk Jakarta,

Fitriyanti Jumaetri Sami, 2009, Kandungan Polisiklik Aromatik Hidrokarbon (PAH) DiWilayah Perairan Teluk Doreri Monokwari,

Keputusan Menteri Lingkungan Hidup Nomor 51 Tahun 2004 tentang Baku Mutu Air Laut

Khozanah Munawir, Kadar Polisiklik Aromatik Hidrokarbon (PAH), Dalam Air, Sedimen dan Sampel Biota DiPerairan Teluk KerabatBangka, Pusat Penelitian Oseanografi-LIPI Received 24 September 2007, Accepted 6 December 2007.

Tinalaniati's Blog, Macam-macam limbah, Postedon June11, 2010

International Marine Organization, Marine pollution konvensi marpoll 1973/1978.

Robby Sudarman, Muhammad Edihar, Subardin, 2011, Pengolahan Limbah Minyak Bumi,

Cano-Lerida L, Rose M, Walton P. 2008. Polycyclic aromatic hydrocarbons dalam Bioactive compounds in Food. Gilbert J: Editor. Oxford: Blackwell Publishing.

Chen BH, Wang CY, Chiu CP. 1996. Evaluation of analysis of polycyclic aromatic hydrocarbons in meat products by liquid chromatography. J Agric

\& Food Chem 44: 2244-2251.

Effendi, H. 2003. Telaah kualitas air bagi pengelolaan sumberdaya dan lingkungan perairan. Kanisius. Yogyakarta

Harvey RG. 2011. Historical Overview of Chemical Carcinogenesis dalam Chemical Carcinogenesis. Penning TM editor. Philadelphia: Springer.

Law, R.J., V.J. Dawes., and P. Matthiessen. 1997. Polycyclic Aromatic Hydrocarbons (PAH) in Seawater around England and Wales. Marine Pollution Buletin, Vol. 34, No. 5, pp. 306-322.

Morret S, Conte L, Dean D. 1999. Assessment of polycyclic aromatic hydrocarbons content of smoked fish by means of a fast HPLC/HPLC method. J Agric \& Food Chem 47: 1367-1371.

Neff, JM. 1977. Polycyclic Aromatic Hydrocarbons in the Aquatic Environment. London: Applied Science Publishers. 